\title{
Efektivitas Penerapan Bayar Pascapanen pada Pengembalian Pembiayaan Akad Murabahah Pertanian Padi di Baitul Maal wa Tamwil As Salam, Kramat, Demak
}

\section{Effectiveness of Postharvest Installment Payments on Murabaha Rice Farming Financing in Baitul Maal wa Tamwil As Salam, Kramat, Demak}

\author{
Nana Rodiana, Nunung Nuryartono, Salahuddin El Ayyubi \\ Departemen Ilmu Ekonomi, Fakultas Ekonomi dan Manajemen Institut Pertanian Bogor
}

\begin{abstract}
Agricultural crops greatly depends on the season, since the time of land preparation to harvest. Planting delays due to lack of capital, will result in crop failure or low crop productivity. Islamic microfinance institutions, such as BMT, offersmurabaha financing as one of financing options. Application of murabahais generally followed by monthly installment payments. The condition of most farmers doesn't enable them to have enough income due to pay the main installments with a monthly period. Postharvest payment return system is an alternativemain return of financing. The research result showed the factors that influence farmers in choosing the monthly payment system and postharvest margins on murabaharice farming financing in BMT As Salam, Kramat, Demak using binary logistic regression. The analysis result showed the reason for choosing the payment system significantly influenced rice farmers choice. The chance of postharvest payment is acceptableaccording to the ability of most farmers. The effectiveness of postharvest payment return implementationonmurabaha rice farming financing was measured using a Likert scale. The results showed that postharvest paymentimplementation has been effective in all stages of financing and made a positive impact on farm members.
\end{abstract}

Keywords: BMT, Effectiveness, Likert, Logit, Postharvest payment

\begin{abstract}
Abstrak. Pertanian tanaman pangan sangat tergantung musim, sejak masa pengolahan lahan hingga panen. Keterlambatan tanam karena kekurangan modal, akan mengakibatkan kegagalan panen atau produktivitas tanaman rendah. Lembaga keuangan mikro syariah, seperti BMT, menawarkan pembiayaan, salah satunya pembiayaan akad murabahah.Penerapan akad murabahah umumnya diikuti dengan angsuran pembayaran bulanan. Kondisi petani kebanyakan tidak memungkinkan mereka untuk memiliki penghasilan yang cukup untuk membayar angsuran pokok dengan rentang waktu bulanan. Sistem pengembalian pembiayaan dengan bayar pascapanen (yarnen) adalah alternatif pengembalian pokok pembiayaan. Penelitian ini menganalisis faktor yang memengaruhi petani dalam memilih sistem pembayaran margin bulanan dan yarnen pada pembiayaan akad murabahah pertanian padi di BMT As Salam, Kramat, Demak menggunakan regresi logistik biner. Hasil penelitian menunjukkan alasan memilih sistem pembayaran berpengaruh signifikan terhadap pilihan petani padi. Responden memiliki peluang lebih besar memilih yarnen karena sesuai kemampuan pembayaran. Efektivitas penerapan yarnenpada pengembalian pembiayaan akad murabahah pertanian padi diukur menggunakan skala Likert. Hasil penelitian menunjukkan penerapan yarnentersebut sudah efektif di seluruh tahapan pembiayaan dan memberi dampak positif pada usahatani anggota.
\end{abstract}

Kata kunci: BMT, Efektivitas, Likert, Logit, Yarnen 


\section{PENDAHULUAN}

Jumlah penduduk Indonesia terus meningkat.Data Badan Pusat Statistik (BPS) memaparkan tahun 2010 jumlah penduduk Indonesia mencapai 237.641 juta jiwa.Peningkatan jumlah penduduk Indonesia yang mayoritas pengkonsumsi utama padi-padian membuat tanaman pangan ini tetap menduduki urutan pertama dalam tanaman pangan yang banyak dikonsumsi dibandingkan golongan tanaman pangan lain, seperti umbi-umbian dan kacang-kacangan.

Tabel 1 Konsumsi rata-rata per kapita beberapa bahan makanan di Indonesia, 2013

\begin{tabular}{clr}
\hline No. & Bahan makanan & Jumlah $(\mathrm{kg})$ \\
\hline 1 & Beras & 85.514 \\
2 & Jagung basah berkulit & 0.574 \\
3 & Jagung pipilan & 1.304 \\
4 & Ketela pohon & 3.494 \\
5 & Ketela rambat & 2.346 \\
6 & Kacang kedelai & 0.052 \\
\hline
\end{tabular}

Sumber: Survei Sosial Ekonomi Nasional, 2013 (Kementerian Pertanian RI)

Pertanian tanaman pangan sangat tergantung musim, sejak masa pengolahan lahan hingga panen. Keterlambatan tanam karena kekurangan modal, akan mengakibatkan kegagalan panen atau produktivitas tanaman yang rendah. Ketepatan waktu dalam memperoleh modal ini merupakan kriteria yang sangat penting bagi petani (Tampubolon 2002). Selain itu, menurut Soekartawi (2002), pembentukan modal bertujuan meningkatkan produksi dan pendapatan usahatani. Pembentukan modal dapat dilakukan petani melalui dana pinjaman atau kredit.

Lembaga keuangan konvensional sebagai salah satu lembaga yang menyalurkan kredit, menetapkan bunga tetap untuk kredit yang diajukan anggota dan harus dikembalikan ketika jatuh tempo. Lembaga keuangan syariah menawarkan penyediaan dana tanpa bunga. Penyediaan dana atau tagihan/piutang dalam lembaga keuangan syariah ini disebut pembiayaan. Baitul Maal wat Tamwil (BMT) sebagai salah satu lembaga keuangan mikro syariah memiliki kegiatan pembiayaan usaha kecil bawah (mikro) (Soemitra 2009). Salah satu bentuk pembiayaan usaha kecil mikro adalah pembiayaan murabahah yang merupakan akad jual beli dengan margin keuntungan yang disepakati.Pembiayaan murabahah pada BMT cenderung lebih dominan dibandingkan jenis pembiayaan lain seperti mudharabah dan musyarakah karena pihak yang menerima pembiayaan tidak perlu membuat laporan rutin penggunaan dana pembiayaan dan risiko yang diterima BMT lebih kecil.

Penerapan akad murabahah umumnya diikuti dengan angsuran pembayaran bulanan. Kondisi petani kebanyakan tidak memungkinkan untuk memiliki penghasilan yang cukup untuk membayar angsuran pokok dengan rentang waktu bulanan karena penghasilan utama baru akan didapat saat panen. Pada tanaman padi dibutuhkan waktu 4 hingga 5 bulan, sejak tanam hingga panen. Oleh karena itu, petani membutuhkan sistem pengembalian pembiayaan yang sesuai dengan kondisi petani. Sistem pengembalian pembiayaan dengan bayar pascapanen (yarnen) adalah pengembalian pembiayaan pada akhir periode pembiayaan atau dalam hal ini setelah panen. Yarnen dapat menjadi alternatif pengembalian pembiayaan pada akad murabahah dengan pertimbangan bahwa petani baru memiliki penghasilan setelah masa panen. 
Demak memiliki BMT yang fokus pembiayaannya pada pertanian padi, yaitu BMT AsSalam, Kramat, Demak. Sebesar $75 \%$ pembiayaannya disalurkan pada sektor pertanian. BMT As Salam merupakan salah satu BMT yang menerapkan sistem pengembalian pembiayaan yarnen. Petani yang menerima pembiayaan murabahah dari BMT As Salam akan mengembalikan pokok pembiayaannya setelah panen, sedangkan margin pembiayaan dapat dibayar bulanan ataupun yarnen. Berbagai sistem pengembalian pembiayaan yang diterapkan BMT ini disesuaikan dengan kondisi petani setempat. Sistem pengembalian pembiayaan yarnen akad murabahah di BMT As Salam mencapai $90 \%$ dari total pembiayaan murabahah yang diberikan.

Berdasarkan permasalahan tersebut, maka tujuan penelitian ini adalah sebagai berikut:

1. Menganalisis faktor yang memengaruhi petani padi dalam memilih sistem pembayaran margin bulanan dan margin yarnenpada pembiayaanakad murabahahpertanian padi di BMT As-Salam, Kramat

2. Menganalisis tingkat efektivitas penerapan yarnen pada pengembalian pembiayaan akad murabahah pertanian padi di BMT As-Salam, Kramat

\section{TINJAUAN PUSTAKA}

\section{Pembiayaan Syariah dalam Pertanian Tanaman Pangan}

Pinjam-meminjam adalah akad sosial, bukan komersial, sehingga tidak diperbolehkan membebankan tambahan atas pokok pinjamannya (Ashari dan Saptana 2005). Pinjaman dengan tambahan atas pokok pinjamannya dapat dikategorikan sebagai riba. Dalam lembaga pembiayaan syariah, pinjaman tidak disebut kredit, tetapi pembiayaan. Kegiatan penyaluran dana berupa pembiayaan, antara lain menggunakan akad Mudharabah, Musyarakah, Murabahah, Salam,Istishna', Ijarah, Ijarah Muntahiyah bit Tamlik (IMBT), dan Qardh.

Pembiayaan dengan skim syariah memerlukan analisa mendalam terhadap kebutuhan petani, keadaan dan prospek usaha, serta penerapan akad yang sesuai syariah, sehingga tidak ada pihak yang dirugikan, baik petani maupun lembaga keuangan (Saptia 2009). Usaha subsektor tanaman pangan, khususnya padi, yang mencakup subsistem hulu dan hilir, memungkinkan penggunaan skim pembiayaan syariah pada masing-masing subsistem.

\section{Karakteristik Pertanian Tanaman Pangan}

Pertanian, khususnya pertanian tanaman pangan, merupakan salah satu sektor penting dalam memenuhi kebutuhan pangan manusia. Di Indonesia, pertanian tanaman pangan turut memegang peranan penting dalam perekonomian nasional. Pertanian ini mampu menyumbang produk domestik bruto (PDB) yang relatif besar. Akan tetapi, pencapaian kedua peranan penting tersebut masih memiliki kendala, terutama dalam pemodalan.

Pertanian tanaman pangan memiliki karakteristik khusus terkait masa tanam dan pendapatan yang diperoleh petani.Masa tanam pertanian pangan bergantung musim, seperti padi, membutuhkan waktu 4-5 bulan mulai dari penanaman hingga pemanenan. Hal ini berpengaruh pada pendapatan petani yang bergantung pada hasil panen. 
Menurut Saptia (2009), petani tanaman pangan memiliki beberapa permasalahan, antara lain:

1. Produk pertanian pangan tergantung musim

2. Rata-rata produk pertanian dihasilkan di pedesaan, sehingga harus tersedia infrastruktur yang memadai

3. Produk pertanian tanaman pangan biasanya dalam jumlah besar dan mudah busuk

4. Rata-rata petani tidak memiliki sertifikat tanah sebagai jaminan dalam mengajukan pembiayaan ke lembaga perbankan

5. Kelembagaan keuangan sektor pertanian di tingkat pedesaan masih jarang ditemukan, sehingga akses petani ke lembaga keuangan sangat terbatas

Karakteristik khusus dan berbagai permasalahan ini menuntut lembaga keuangan yang menyalurkan pembiayaan pada sektor pertanian memiliki mekanisme tertentu, salah satunya dalam pengembalian kredit atau pembiayaan.

\section{Baitul Maal wat Tamwil}

Baitul Maal wat Tamwil (BMT) terdiri atas kata Baitul Maal (rumah harta) dan Baitul Tamwil (rumah pengembangan harta). BMT merupakan balai usaha mandiri terpadu yang memiliki kegiatan pengembangan usaha-usaha produktif dan investasi dalam meningkatkan kualitas hidup pengusaha kecil (Soemitra 2009). BMT sebagai lembaga keuangan berfungsi menghimpun dan menyalurkan dana masyarakat sesuai prinsip syariah. Menurut Soemitra (2008), penyelenggaraan BMT didasarkan pada prinsipprinsip utama, di antaranya keimanan dan ketakwaan pada Allah SWT, keterpaduan, kekeluargaan, kebersamaan, kemandirian, profesionalisme, dan konsisten.

Sebagai lembaga keuangan mikro syariah non bank, BMT memiliki ciri-ciri utama, antara lain (Soemitra 2008):

1. Berorientasi bisnis, mencari laba bersama, meningkatkan pemanfaatan ekonomi untuk anggota dan lingkungan

2. Dapat dimanfaatkan untuk mengefektifkan penggunaan zakat, infaq, sedekah, walaupun bukan lembaga sosial

3. Ditumbuhkan dari bawah berlandaskan peran serta masyarakat

4. Milik bersama masyarakat kecil dan bawah dari lingkungan BMT itu sendiri, bukan milik orang perseorangan

\section{Penyaluran Dana Baitul Maal wat Tamwil}

BMT menggunakan akad pembiayaan dengan bagi hasil, yaitu mudharabah dan musyarakah, akad pembiayaan dengan margin, yaitu murabahah dan bai bithaman ajil (BBA), dan pembiayaan qardhul hasan.

Menurut Choudury dalam Kusmiyati (2007), pembiayaan murabahah lebih dominan terjadi karena pembiayaan ini cenderung memiliki risiko lebih kecil dan lebih mengamankan bagi shareholder. Akad murabahah merupakan akad jual beli dengan kesepakatan margin keuntungan dari harga pokok suatu barang. Lembaga keuangan 
syariah akan membelikan barang yang dibutuhkan nasabah dan pembayaran dari pengadaan barang dilakukan secara tunai atau tangguh sesuai kesepakatan.

Rasulullah SAW memperbolehkan praktik murabahah. Hal ini berdasarkan sabda Rasulullah:

"Ada tiga hal yang mengandung keberkahan: jual beli tidak secara tunai, muqaradhah (mudharabah), dan mencampur gandum dengan jewawut untuk keperluan rumah tangga, bukan untuk dijual." (H.R. Ibnu Majah) ${ }^{\mathrm{a}}$

Syarat dan rukun jual beli murabahah menurut Al-Kasani dalam Nawawi (2012), antara lain:

1. Pembeli kedua harus mengetahui harga pokok (harga beli). Hal ini merupakan syarat mutlak murabahah.

2. Kejelasan keuntungan yang diinginkan penjual kedua. Keuntungan merupakan persentase dari harga beli. Keuntungan ditambah harga pokok akan menjadi harga jual untuk pembeli kedua. Harga jual ini merupakan syarat sahnya jual beli.

3. Modal untuk membeli objek transaksi harus terdapat padanannya di pasaran.

4. Objek transaksi dan alat pembayaran tidak boleh berupa barang ribawi

5. Akad jual beli antara pembeli pertama dengan penjual pertama harus sah.

6. Murabahah disandarkan pada sebuah kepercayaan antara pembeli dan penjual. Pembeli percaya atas informasi yang diberikan penjual, sehingga penjual tidak boleh berkhianat.

Seperti halnya jual beli lainnya, murabahah juga harus disertai sighah (ijab dan qabul). Menurut Zuhaily dalam Nawawi (2012), beberapa syarat harus dipenuhi dalam ijab dan qabul. Syarat-syarat ijab dan qabul antara lain adanya kejelasan maksud dari kedua pihak yang berakad, kesesuaian antara ijab dan qabul, dan pertemuan ijab dan qabul dalam satu majlis. Ketika melakukan sighah, kesepakatan mengenai waktu pengembalian pembiayaan juga harus disepakati, baik pembayaran secara tunai maupun tangguh dengan mengangsur atau membayar saat jatuh tempo.

Akad murabahah dalam pembiayaan sektor pertanian dapat diterapkan untuk penyediaan alat dan mesin pertanian, bibit, benih, pupuk, maupun pestisida. Petani dapat mengembalikan pembiayaan beserta margin yang telah disepakati, secara tunai maupun tangguh dengan mengangsur atau bayar pascapanen (yarnen). Yarnen meringankan petani, terutama petani tanaman pangan yang membutuhkan waktu bulanan untuk mendapatkan penghasilan dari hasil panennya.

\section{Efektivitas Penerapan Yarnen}

Efektivitas adalah kriteria yang menunjukkan apakah suatu hal yang dilakukan telah mencapai tujuan yang diinginkan, bukan menunjukkan berapa besar biaya yang dikeluarkan untuk mencapai tujuan tersebut. Efektivitas pembiayaan menunjukkan sejauh mana pembiayaan mencapai tujuan yang diinginkan sesuai mekanisme yang telah dilaksanakan.

\footnotetext{
${ }^{a}$ Fatwa DSN MUI No. 04/DSN-MUI/IV/2000 Tentang Murabahah
} 
Penyediaan sarana dan prasarana untuk melakukan produksi pertanian dilakukan melalui kredit produksi yang akan dibayar dalam bentuk hasil usahatani. Kredit pertanian semacam ini telah digunakan secara efektif di banyak negara. Dengan pembayaran yang dilakukan setelah panen (yarnen), petani dapat membeli sarana dan prasarana produksi serta memperhitungkan berapa banyak padi yang akan dihasilkan dari hasil panennya untuk membayar kredit (Mosher 1987).

Admiral dalam Anjani (2013) menyatakan bahwa efektif atau tidaknya suatu penyaluran pembiayaan pada BMT dapat dinilai berdasarkan beberapa parameter, antara lain persyaratan peminjaman, prosedur peminjaman, realisasi pembiayaan, besar kecilnya biaya administrasi, pelayanan petugas bank, lokasi bank, jaminan/agunan, pengetahuan dan partisipasi nasabah/calon nasabah, serta dampak positif yang diberikan.

Efektivitas penerapan yarnen pada pengembalian pembiayaaan akad murabahahdapat dilihat dari tercapai tidaknya tujuan dari penerapan alternatif pengembalian pembayaran tersebut.Pengembalian dengan pola yarnen bertujuan meringankan petani, yang baru memiliki penghasilan setelah panen.

\section{Penelitian Terdahulu}

Menurut Saptia (2009), keberadaan kredit atau pembiayaan sangat dibutuhkan oleh petani dalam upaya mengatasi keterbatasan modal untuk meningkatkan hasil produksi. Kredit sudah menjadi bagian hidup dan ekonomi usahatani karena apabila kredit tidak tersedia maka tingkat produksi dan pendapatan usahatani akan menurun. Berdasarkan penelitian yang dilakukan di Sukabumi dan Yogyakarta ini, skim pembiayaan syariah di sektor pertanian, khususnya tanaman pangan masih jarang ditemukan. Pembiayaan pertanian tanaman pangan dengan sistem syariah, terbatas pada risk sharing antara pemerintah dengan perbankan yang diwujudkan dalam kredit program. Kebijakan kredit program pemerintah ini masih menunjukkan banyak kelemahan, sehingga kurang efektif.

Aminullah (2014) melakukan penelitian mengenai pola pemberdayaan petani peserta Gerakan Peningkatan Produktivitas Pangan Berbasis Korporasi (GP3K) untuk menganalisis dampak pengembalian pinjaman dengan yarnen pada GP3K terhadap petani. Hasil penelitian menunjukkan paket pinjaman dana umum Pola Kemitraan Bina Lingkungan berupa penyediaan sarana produksi petani dengan pola yarnen memberikan dampak positif bagi petani.

Anjani (2013) melakukan analisis kualitatif bersifat deskriptif untuk mengetahui apakah pembiayaan pada sektor pertanian yang dilakukan KBMT Ibaadurrahman, Bogor telah efektif dalam hal pengelolaannya serta dampak yang ditimbulkan terhadap nasabah. Penilaian efektivitas pembiayaan dilihat dari aspek pengajuan, pencairan, pemanfaatan, pengembalian, dan dampak pembiayaan terhadap nasabah. Efektivitas pembiayaan dinilai berdasarkan persepsi responden yang diwawancarai. Pengukuran efektivitas pembiayaan yang dilakukan oleh KBMT Ibaadurrahman berdasarkan penilaian nasabah diukur dengan alat bantu skala Likert. Hasil penelitian menunjukkan efektivitas pembiayaan pada KBMT berdasarkan hasil penilaian responden dapat dikategorikan efektif. Akan tetapi, pada tahap pencairan dan pengembalian pembiayaan masih memiliki nilai efektivitas yang cukup rendah.

Nawai dan Shariff (2012) menganalisis faktor-faktor yang memengaruhi pengembalian pada program pembiayaan mikro di Malaysia menggunakan regresi logistik multinomial dengan variabel dependen berupa dummy yang terbagi tiga, yaitu nasabah yang tidak memiliki masalah pengembalian, pernah melakukan pelanggaran, dan gagal bayar. Hasil 
penelitian menunjukkan faktor-faktor yang signifikan memengaruhi pengembalian pada program pembiayaan mikro di Malaysia adalah jenis kelamin, agama, jarak ke kantor pembiayaan, etika berbisnis, total penjualan per bulan, total penerimaan pembiayaan, pengawasan pembiayaan, dan keterlambatan pencairan pembiayaan.

\section{Kerangka Pemikiran}

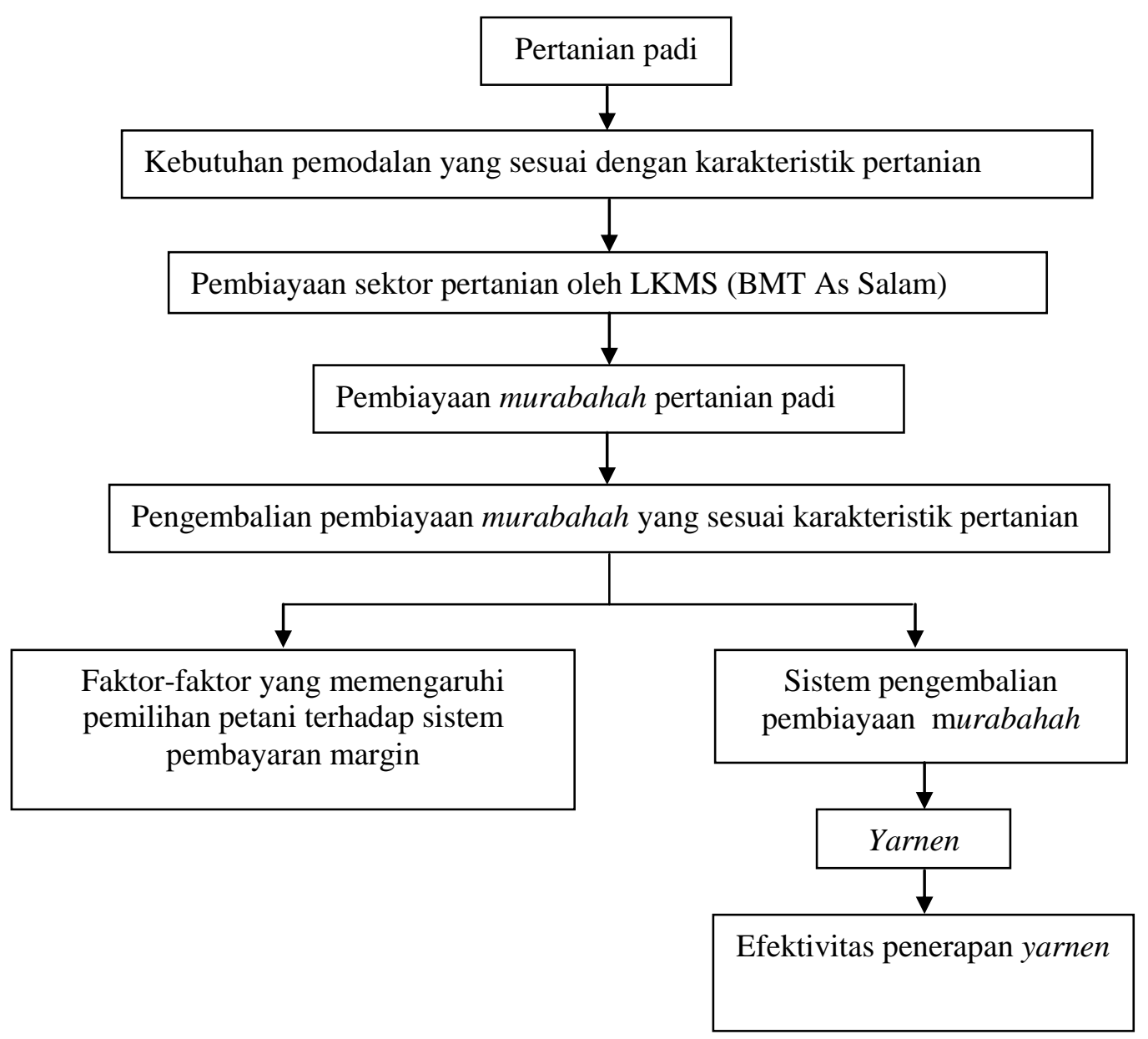

Gambar 1 Kerangka pemikiran efektivitas penerapan yarnen pada pembiayaan murabahah pertanian padi

\section{METODE PENELITIAN}

\section{Jenis dan Sumber Data}

Jenis data yang akan digunakan dalam penelitian ini adalah data primer dan data sekunder, baik bersifat kualitatif maupun kuantitatif. Data primer diperoleh melalui observasi lapangan, metode wawancara dengan alat bantu kuesioner, dan wawancara langsung dengan pihak BMT As Salam. Data sekunder diperoleh dari berbagai arsip dan administrasi BMT As Salam, BPS, Kementerian Pertanian RI, jurnal, buku, serta sumber literatur lain yang diperlukan untuk menunjang penelitian ini. 


\section{Lokasi dan Waktu Penelitian}

Penelitian ini dilaksanakan di BMT As-Salam, Kramat, Demak. Pemilihan lokasi dilakukan secara sengaja dengan pertimbangan BMT As-Salam merupakan salah satu BMT yang menerapkan sistem pengembalian pembiayaan murabahah dengan yarnen pada pembiayaan sektor pertanian serta memiliki proporsi pembiayaan pertanian sebesar 75\%. Pengambilan data penelitian ini dilakukan pada Maret 2014.

\section{Metode Penentuan Sampel}

Penentuan sampel dalam penelitian ini menggunakan teknik purposive sampling. Purposive sampling adalah teknik penentuan sampel dengan pertimbangan kriteria yang telah ditentukan peneliti. Kriteria sampel penelitian ini adalah petani padi yang menerima pembiayaan murabahah di BMT As Salam, Kramat, lebih dari satu kali dan sudah melunasi pengembaliannya. Sampel dalam penelitian ini sebanyak 30 orang. Wawancara dilakukan berdasarkan kuesioner yang telah disiapkan sebagai panduan.

\section{Metode Pengolahan dan Analisis Data}

\section{Analisis Deskriptif}

Analisis deskriptif menggambarkan suatu data yang akan digolongkan menjadi data tunggal maupun kelompok. Tujuan analisis deskriptif untuk menggambarkan secara sistematis data yang faktual dan akurat mengenai fakta-fakta serta hubungan antarfenomena yang diteliti (Riduwan dan Sunarto, 2011). Penelitian ini akanmenunjukkan karakteristik umum dan karakteristik usahatani petani padi. Data untuk analisis deskriptif diperoleh melalui kuesioner yang diberikan pada responden.

\section{Analisis Regresi}

Faktor-faktor yang memengaruhi petani padi dalam memilih sistem pengembalian margin bulanan dan margin yarnen dianalisis dengan regresi logistik biner sebagai berikut:

$$
\mathrm{Pi}=\mathrm{F}(\mathrm{Zi})=\mathrm{F}(\alpha+\beta \mathrm{Xi})=\frac{1}{1+\mathrm{e}^{-(\alpha+\beta \mathrm{Xi})}}
$$

Keterangan:

$\mathrm{Pi}=$ Probabilitas petani padi untuk memilih sistem pembayaran margin

$\mathrm{P}_{1}=$ Petani padi memilih pembayaran margin yarnen

$\mathrm{P}_{2}=$ Petani padi memilih pembayaran margin bulanan

$\alpha=$ Intersep

$\beta_{\mathrm{i}}=$ Parameter peubah $\mathrm{X}_{\mathrm{i}}$

$\mathrm{X}_{1}=$ Dummy alasan pemilihan sistem pembayaran; (1 jika pendapatan hanya berasal dari pertanian, 0 jika sesuai kemampuan pembayaran) 
$\mathrm{X}_{2}=$ Dummy alasan pemilihan sistem pembayaran; (1 jika lebih ringan, jika sesuai kemampuan pembayaran)

$\mathrm{X}_{3}=$ Rata-rata pendapatan rumah tangga per bulan (Rupiah)

$\mathrm{X}_{4}=$ Rata-rata konsumsi rumah tangga per bulan (Rupiah)

$\mathrm{X}_{5}=$ Omzet usaha per musim (Rupiah)

$\mathrm{X}_{6}=$ Dummy plafon pembiayaan (Rupiah); (1 jika $<$ Rp5juta, 0 jika

$\geq$ Rp5juta)

\section{Analisis Efektivitas}

Data yang dianalisis diperoleh dari kuesioner penilaian efektivitas yang berisi beberapa pertanyaan dalam aspek pengajuan, pencairan, pemanfaatan, pengembalian pembiayaan, dan aspek ekonomi responden. Data tersebut diukur dengan skala Likert.

Pernyataan responden dalam kuesioner penilaian efektivitas diklasifikasikan menjadi empat kategori, yaitu efektif, cukup efektif, kurang efektif, dan tidak efektif. Pembagian penilaian ini digunakan untuk mengidentifikasi tingkat efektivitas penerapanyarnen pada pengembalian akad murabahah agar analisis lebih tajam. Penentuan skor bagi tiap pertanyaan berdasarkan rumus (Akdon dan Riduwan 2009):

Skor $=$ Jumlah responden yang memilih jawaban tertentu $\mathrm{x}$ Nilai skor tiap

$$
\text { pertanyaan }
$$

$$
\text { Total Skor }=\text { Jumlah skor pada tiap kategori }
$$

Total skor untuk tiap kategori berkisar antara 90-270. Kisaran skor ini diperoleh dari hasil perkalian antara skor terendah dan tertinggi dengan jumlah pertanyaan dalam tiap aspek dan jumlah responden. Pengelompokkan kriteria efektivitas tiap aspek dihitung berdasarkan rumus (Akdon dan Riduwan 2009):

$$
\text { Persentase Efektivitas }=\frac{\text { Total skor tiap kategori }}{270} \times 100 \%
$$

Berdasarkan rumus tersebut, kriteria efektivitas tiap aspek adalah:

1. Angka $0 \%-25 \%=$ Tidak efektif

2. Angka $26 \%-50 \%=$ Kurang efektif

3. Angka $51 \%-75 \%=$ Cukup efektif

4. Angka $76 \%-100 \%=$ Efektif 


\section{GAMBARAN UMUM BMT AS SALAM}

Koperasi Serba Usaha (KSU) BMT As Salam merupakan salah satu Lembaga Keuangan Mikro Syariah (LKMS) yang berada di Kabupaten Demak. BMT As Salam berawal dalam bentuk arisan warga sekitar Desa Mangunrejo, Kebonagung, Demak yang diinisiasi oleh 3 orang pada 2003. Kebutuhan yang dirasa semakin bertambah, memunculkan gagasan untuk membuat lembaga keuangan mikro syariah yang dapat membantu warga sekitar dalam memenuhi kebutuhannya. Pada 28 Oktober 2004, BMT As Salam resmi berdiri sebagai LKMS berbadan hukum koperasi BMT As Salam berbadan hukum koperasi dengan No. 68/BH.Kop.11-03/X/2004. BMT As Salam memiliki kantor pusat di Desa Mangunrejo dan juga kantor cabang di Desa Mangunrejo, Desa Kramat, serta kantor cabang pembantu di Desa Sarimulyo dan Desa Sambung. Kantor cabang di Desa Kramat didirikan pada 2011.BMT As Salam, Kramat berkantor di Desa Kramat RT 04 RW 01, Kecamatan Dempet, Demak. Wilayah kerjanya meliputi Desa Kramat, Wedean, Harjowinangun, Sambiroto, Gedangalas, Tempel, Gompeng, Krasak, dan desa-desa lain yang berada di Kecamatan Dempet maupun Kebonagung.

\section{Mekanisme Pembiayaan Murabahah Yarnen}

Pengajuan pembiayaan murabahah yarnen pertanian padi di BMT As Salam, Kramat memiliki berbagai persyaratan yang disesuaikan dengan plafon pembiayaan yang diterima anggota. Plafon pembiayaan sebesar Rp 1 juta sampai Rp 10 juta hanya melampirkan fotokopi KTP dan KK, sedangkan plafon pembiayaan di atas Rp 10 juta perlu penandatangan akta dengan notaris dan persyaratan lainnya. Gambar 2 menunjukkan mekanisme pembiayaan murabahah yarnen dari tahap pengajuan hingga pengembalian. 


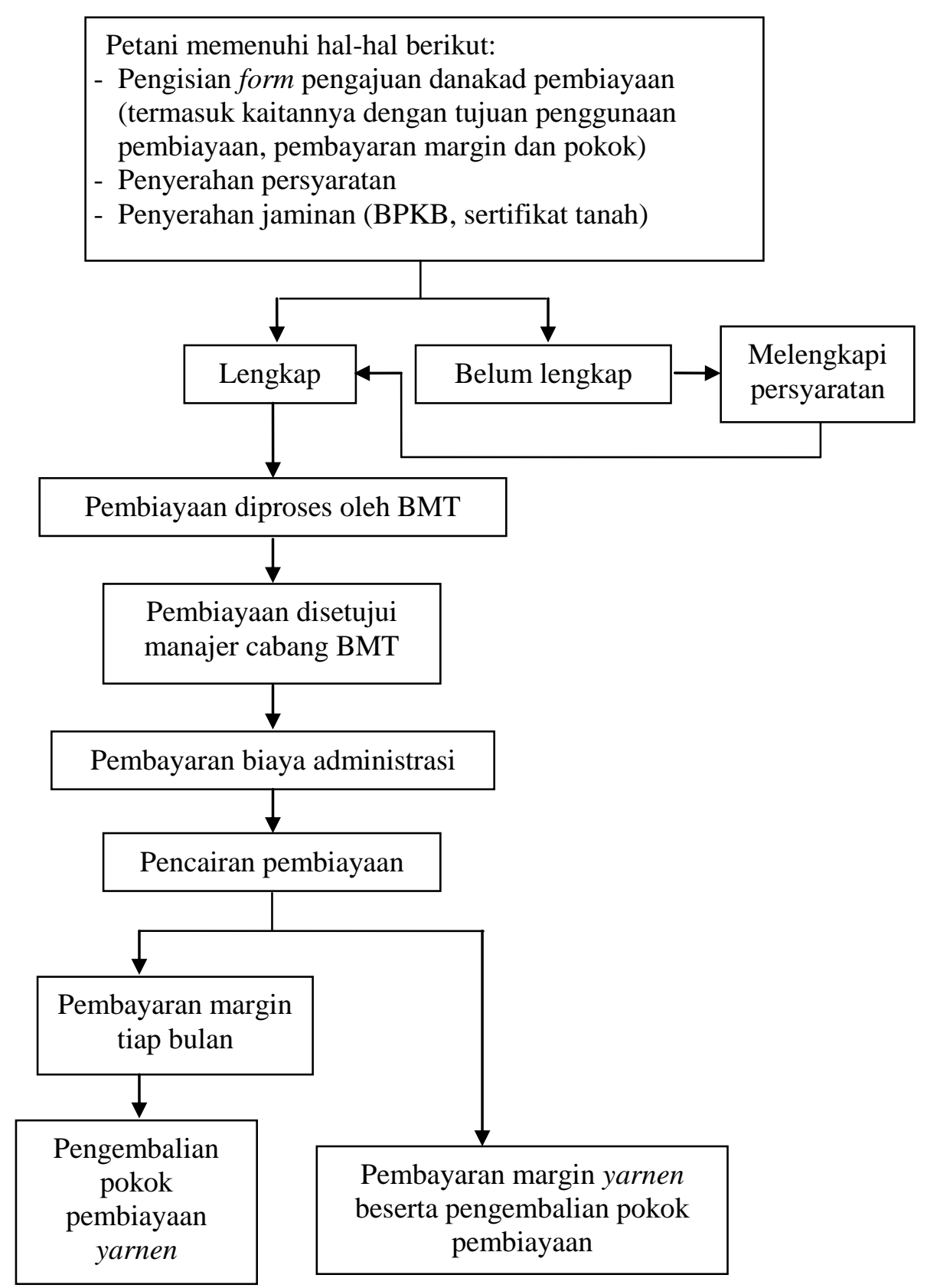

Gambar 2 Mekanisme pembiayaan murabahah yarnen

BMT As Salam telah mengalami berbagai penyesuaian jangka waktu pengembalian pembiayaan murabahah pertanian agar sesuai dengan kondisi dan kemampuan petani padi. Awalnya, pengembalian pembiayaan dilakukan mingguan. Sistem ini bertahan selama 2 tahun. Karena anggota atau petani padi sering mengalami keterlambatan pengembalian, BMT memperpanjang jangka waktunya menjadi 4 bulan disesuaikan dengan waktu panen padi.Hal ini ternyata belum mampu meminimalisasi keterlambatan pengembalian karena petani padi tidak langsung mampu menjual hasil panennya setelah panen.BMT mengubah janga waktu pengembalian menjadi 6 bulan dengan pertimbangan, petani memiliki waktu 2 bulan setelah masa panen untuk menjual hasil panennya. Jangka waktu ini yang digunakan BMT As Salam hingga saat ini. 
BMT As Salam hanya menerapkan akad murabahah pada akad jual beli sektor pertanian. Berdasarkan hasil wawancara dengan pihak BMT, penerapan akad salam dalam jual beli di sektor pertanian tidak sesuai dengan BMT karena BMT tidak membeli hasil panen, melainkan menerima pembayaran langsung dengan uang tunai.

\section{EFEKTIVITAS PENERAPAN BAYAR PASCAPANEN PADA PENGEMBALIAN PEMBIAYAAN AKADA MURABAHAH PERTANIAN PADI DI BMT AS SALAM, KRAMAT, DEMAK}

\section{Karakteristik Responden}

\section{Rata-rata Pendapatan dan Konsumsi Rumah Tangga (RT) per Bulan}

Rata-rata pendapatan RT sebagian besar respondenberkisar antara Rp 1-5 juta.Sebanyak 23 orang atau $76.6 \%$ responden memiliki pendapatan berkisar antara $\mathrm{Rp} 1-5$ juta. Pendapatan ini diperoleh dari rata-rata pendapatan usahatani jika dijadikan per bulan, maupun pendapatan lain yang berasal dari usaha non pertanian. Karakteristik responden berdasarkan rata-rata pendapatan RT per bulan dapat dilihat pada Tabel 2.

Tabel 2 Karakteristik responden berdasarkan rata-rata pendapatan RT per bulan

\begin{tabular}{ccc}
\hline Rata-rata pendapatan & Jumlah (orang) & Persentase $(\%)$ \\
RT/bulan (Rp) & 2 & 6.7 \\
\hline 1 juta & 23 & 76.6 \\
$1-5$ juta & 3 & 10 \\
$5.5-9.5$ juta & 2 & 6.7 \\
$>10$ juta & 30 & 100 \\
Total & & \\
\hline
\end{tabular}

Sebanyak 16 orang atau 53.3\% responden memiliki rata-rata konsumsi per bulan kurang dari $\mathrm{Rp} 1$ juta.Penghitungan pengeluaran untuk konsumsi yang dilakukan responden meliputi biaya makan, pendidikan, kesehatan, air, dan listrik.Karakteristik responden berdasarkan rata-rata konsumsi RT per bulan dapat dilihat pada Tabel 3.

Tabel 3 Karakteristik responden berdasarkan rata-rata konsumsi RT per bulan

\begin{tabular}{ccc}
\hline Rata-rata konsumsi & Jumlah (orang) & Persentase $(\%)$ \\
RT/bulan (Rp) & 16 & 53.3 \\
\hline 1 juta & 11 & 36.7 \\
$1-2$ juta & 2 & 6.7 \\
$2.5-3.5$ juta & 1 & 3.3 \\
$>3.5$ juta & 30 & 100 \\
Total & & \\
\hline
\end{tabular}

Rata-rata pendapatan dan konsumsi RT per bulan responden menunjukkan sebagian besar responden mampu memenuhi kebutuhannya dengan pendapatan yang didapat per bulan.

\section{Omzet Usahatani per Musim}

Omzet usahatani per musim sebagian besar responden, yaitu 14 orang atau 46.7\%, mencapai sekitar Rp11-21 juta dalam kurun waktu 4-6 bulan. Berdasarkan hasil tersebut, 
diketahui dalam kurun waktu 4-6 bulan, petani padi dapat memperoleh penjualan hasil panen berkisar antara Rp11-21 juta.Karakteristik responden berdasarkan omzet usahatani per musim setelah mendapat pembiayaan dapat dlihat pada Tabel 4.

Tabel 4 Karakteristik responden berdasarkan omzet usahatani per musim setelah mendapat pembiayaan

\begin{tabular}{ccc}
\hline Omzet usahatani per & Jumlah (orang) & Persentase $(\%)$ \\
musim (juta rupiah) & 2 & 6.7 \\
55 & 9 & 30 \\
$11-21$ & 14 & 46.7 \\
$22-32$ & 4 & 13.3 \\
$>32$ & 1 & 3.3 \\
Total & 30 & 100 \\
\hline
\end{tabular}

\section{Plafon Pembiayaan}

Plafon pembiayaan dibagi menjadi tiga sesuai dengan tingkatan margin yang digunakan oleh BMT As Salam, yaitu 3.5\% untuk pembiayaan Rp 1-4 juta, 3.25\% untuk Rp 5-9 juta, dan 3\% untuk Rp 10-19 juta. Sebagian besar responden, yaitu 29 dari 30 orang atau 96.7\% responden pernah menerima pembiayaan pada kisaran Rp 1-4 juta. Sebanyak 10 dari 30 orang atau $33.3 \%$ responden pernah menerima pembiayaan pada kisaran Rp 5-9 juta. Hanya 3 dari 30 orang atau $10 \%$ responden yang pernah menerima pembiayaan pada kisaran Rp 10-19 juta. Karakteristik responden berdasarkan plafon pembiayaan dapat dilihat pada Tabel 5.

Tabel 5 Karakteristik responden berdasarkan plafon pembiayaan

\begin{tabular}{ccc}
\hline Plafon pembiayaan $(\mathrm{Rp})$ & Jumlah (orang) & Persentase $(\%)$ \\
\hline 1-4 juta & 29 dari 30 & 96.7 \\
5-9 juta & 10 dari 30 & 33.3 \\
10-19 juta & 3 dari 30 & 10 \\
\hline
\end{tabular}

\section{Faktor-faktor yang Memengaruhi Petani Padi dalam Memilih Sistem Pembayaran Margin Bulanan dan Margin Yarnen}

Analisis faktor-faktor yang memengaruhi petani padi dalam memilih sistem pembayaran margin akad murabahah dilakukan dengan regresi logistik biner atau model logit (Tabel 6). Hasil pendugaan parameter menunjukkan model mampu mengklasifikasikan secara keseluruhan responden yang memilih margin bulanan maupun margin yarnen sebesar $86.7 \%$. Dari total 17 responden yang memilih margin bulanan, 15 responden tepat diklasifikasikan memilih margin bulanan dan 2 responden diprediksi memilih margin yarnen, sehingga ketepatan klasifikasi $88.2 \%$. Dari total 13 responden yang memilih margin yarnen, 11 responden tepat diklasifikasikan memilih margin yarnen dan 2 responden diprediksi memilih margin bulanan, sehingga ketepatan klasifikasi $84.6 \%$. Hasil uji Chi Square Hosmer dan Lemeshow Test menunjukkan nilai Chi Square sebesar 2.246 dengan p-value $0.973>0.05$, sehingga dapat disimpulkan bahwa model logit secara keseluruhan dapat menjelaskan faktor-faktor yang memengaruhipetani padi dalam memilih sistem pembayaran margin bulanan dan margin yarnen. 
Tabel 2 Faktor-faktor yang memengaruhi petani padi dalam memilih sistem pembayaran margin akad murabahah

\begin{tabular}{llll}
\hline \multirow{2}{*}{\multicolumn{1}{c}{ Variabel }} & \multicolumn{3}{c}{ Metode Logit } \\
\cline { 2 - 4 } & Parameter & P-value & Odds Ratio \\
\hline Konstanta & 2.637 & 0.221 & 13.971 \\
Dummy Alasan Pemilihan (1) & 28.583 & 0.998 & $2.591 \mathrm{E} 12$ \\
Dummy Alasan Pemilihan (2) & -3.656 & $0.018^{*}$ & 0.026 \\
Rata-rata Pendapatan RT & 0.034 & 0.465 & 1.035 \\
Rata-rata Konsumsi RT & -0.334 & 0.116 & 0.716 \\
Omzet Usaha & 0.005 & 0.644 & 1.005 \\
Plafon Pembiayaan & -1.073 & 0.693 & 0.342 \\
\hline
\end{tabular}

Keterangan: *signifikan pada taraf nyata $5 \%$

Variabel yang signifikan memengaruhi pada taraf nyata 5\% adalah dummy alasan pemilihan kedua, yaitu alasan memilih sistem pembayaran karena lebih ringan, dengan nilai odds ratio sebesar 0.026. Hasil regresi menunjukkan alasan lebih ringan untuk memilih pembayaran margin yarnen memiliki peluang lebih kecil dibandingkan alasan sesuai kemampuan.Alasan lebih ringan untuk memilih margin yarnen memiliki peluang 0.026 kali dibandingkan dengan alasan sesuai kemampuan pembayaran pada taraf nyata $5 \%$. Hal ini menunjukkan responden memiliki peluang lebih besar memilih yarnen karena sesuai kemampuan pembayaran.

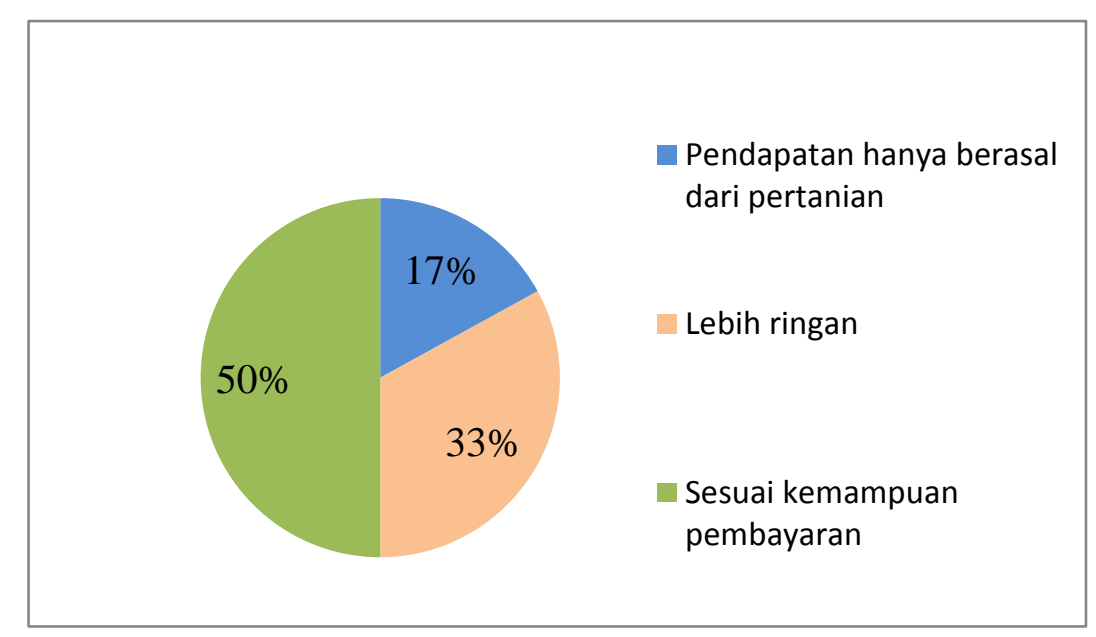

Gambar 3 Alasan petani padi memilih margin bulanan maupun yarnen

Sebanyak $17 \%$ petani padi memilih margin yarnen karena pendapatan hanya berasal dari pertanian, yang baru didapat saat hasil panen sudah terjual.Sebanyak $50 \%$ petani padi memilih margin bulanan ataupunyarnen karena lebih ringan. Petani padi yang memilih bulanan dengan alasan lebih ringan karena petani padi dapat mengangsur setiap bulan, tidak diakumulasi saat akhir periode pembiayaan.Petani padi yang memilih margin yarnen dengan alasan lebih ringan karena petani padi tidak ingin pengembalian pembayaran diakumulasi dengan margin. Sebanyak 33\% petani padi memilih margin bulanan ataupun yarnen karena sesuai kemampuan pembayaran. 


\subsection{Analisis Efektivitas Penerapan Yarnen pada Pengembalian Pembiayaan}

\section{Analisis Efektivitas Penerapan Yarnen Tahap Pengajuan Pembiayaan}

Tahap pengajuan merupakan tahapan awal yang harus dilalui anggota yang ingin mengajukan pembiayaan kepada BMT As Salam, Kramat. Pada tahap ini, BMT As Salam menerapkan beberapa prosedur dan persyaratan, serta jaminan yang harus dipenuhi anggota. Penilaian aspek jaminan pada tahap pengajuan pembiayaan ini dipisahkan dari aspek persyaratan.

Sebanyak $100 \%$ responden menyatakan pengajuan pembiayaan murabahah yarnen memiliki prosedur yang mudah dan persyaratan yang ringan, sehingga mudah dipenuhi. Prosedur yang harus dilalui responden sejak proses pengajuan pembiayaan hingga realisasi pembiayaan dianggap tidak berbelit-belit. Persyaratan pengajuan pembiayaan dianggap ringan atau mudah dipenuhi oleh responden karena responden hanya perlu melampirkan fotokopi KTP dan KK saat mengajukan pembiayaan, di mana pembiayaan yang diajukan responden berkisar di bawah $\mathrm{Rp} 10$ juta. Tiga responden pernah mengajukan pembiayaan di atas $\mathrm{Rp} 10$ juta dengan persyaratan tambahan berupa penandatanganan akta notaris, tetapi responden tersebut menganggap persyaratan ini juga tergolong ringan.

Sebanyak $6.7 \%$ responden menyatakan jaminan berupa BPKB atau sertifikat tanah sebagai persyaratan memperoleh pembiayaan tergolong ringan karena anggota tidak merasa keberatan. Sebanyak $93.3 \%$ responden menyatakan jaminan tersebut tergolong sedang karena anggota cukup keberatan dengan jaminan yang disyaratkan, tetapi tetap mengambil pembiayaan disebabkan kebutuhan akan pembiayaan.

Total skor efektivitas pada tahap pengajuan pembiayaan sebesar 242, dengan persentase sebesar $89.7 \%$. Hal ini menunjukkan bahwa aspek pengajuan pembiayaan yang dilakukan oleh BMT As Salam sudah efektif.

\section{Analisis Efektivitas Penerapan Yarnen Tahap Pencairan Pembiayaan}

Pada tahap pencairan pembiayaan yarnen, anggota yang telah melengkapi persyaratan pembiayaan dapat memperoleh pembiayaan yang diajukan. Anggota BMT As Salam dapat memperoleh pencairan pembiayaan di hari yang sama saat anggota mengajukan pembiayaan, jika persyaratan sudah dipenuhi.

Sebanyak $100 \%$ responden menyatakan realisasi pencairan pembiayaan murabahah yarnen tergolong cepat karena pada hari yang sama ketika mengajukan pembiayaan dan persyaratan telah dipenuhi, dana dapat langsung cair. Penerapan akad murabahah pada BMT As Salam ini belum memenuhi syarat dan rukun akadnya karena tidak ada pengadaan barang yang diinginkan pembeli (petani padi), melainkan hanya pengadaan uang. Hal ini menyebabkan, syarat mutlak murabahah juga tidak terpenuhi, yaitu petani padi harus mengetahui harga pokok (harga beli) barang yang dibutuhkan.Berdasarkan hasil wawancara, BMT pernah menerapkan akad murabahah sesuai dengan syarat dan rukunnya, yaitu adanya pengadaan barang, tetapi BMT menyesuaikan dengan beragamnya kebutuhan petani (bibit, pupuk, upah penggarap lahan). Oleh karena itu, pembiayaan disalurkan dalam bentuk uang.

Sebanyak 96.7\% responden menyatakan biaya administrasi tergolong ringan karena biaya tersebut tidak memberatkan responden, yaitu sebesar 3\%. Sebanyak $3.3 \%$ responden menyatakan biaya tersebut tergolong sedang karena responden mengalami kesulitan mencari dana awal sebesar 3\% dari plafon pembiayaan. Biaya administrasi yang dibebankan kepada anggota dengan plafon pembiayaan di bawah Rp 50 juta 
sebesar 3\% dari plafon pembiayaan, sedangkan pembiayaan di atas atau sama dengan Rp 50 juta sebesar $2 \%$ dari plafon pembiayaan.

Perbedaan persentase biaya administrasi yang disesuaikan dengan plafon pembiayaan tersebut tidak sesuai dengan asas keadilan dalam ekonomi Islam karena petani dengan plafon pembiayaan lebih rendah justru dibebankan dengan persentase biaya administrasi yang lebih tinggi dari petani padi yang menerima plafon pembiayaan tinggi. Perintah untuk berlaku adil dalam transaksi ekonomi diterangkan dalam Q.S. Hud ayat 85:

"Dan Syu'aib berkata: "Hai kaumku, cukupkanlah takaran dan timbangan dengan adil, dan janganlah kamu merugikan manusia terhadap hak-hak mereka dan janganlah kamu membuat kejahatan di muka bumi dengan membuat kerusakan."

BMT As Salam selalu menyetujui permohonan murabahah yarnen yang diminta anggota, di mana besar pengajuan pembiayaan sama dengan realisasi pembiayaan. Hal ini ditunjukkan dengan $100 \%$ responden yang beranggapan BMT As Salam mampu memenuhi permintaan pembiayaan. Pencairan pembiayaan murabahah di BMT As Salam berupa uang tunai bukan sarana produksi pertanian yang dibutuhkan anggota. Berdasarkan hasil wawancara dengan pihak BMT, hal ini disebabkan anggota ingin menggunakan pembiayaan tidak hanya untuk membeli sarana produksi pertanian seperti pupuk dan bibit, melainkan juga untuk upah penggarap lahan tani. Pencegahan terhadap penyelewengan pembiayaan dilakukan saat akad terjadi, dengan cara pengisian kesepakatan akad pembiayaan digunakan untuk keperluan apa saja.

Total skor efektivitas pada tahap pengajuan pembiayaan sebesar 269, dengan persentase sebesar 99.6\%. Hal ini menunjukkan bahwa aspek pencairan pembiayaan yang dilakukan oleh BMT As Salam sudah efektif, tetapi masih ada syarat dan rukun akad, serta prinsip syariah yang belum terpenuhi.

\section{Analisis Efektivitas Penerapan Yarnen Tahap Pemanfaatan Pembiayaan}

Pada tahap pemanfaatan pembiayaan yarnen, BMT As Salam melakukan pengawasan terhadap usahatani anggota dan pelayanan konsultasi perkembangan usaha anggota. Sebanyak 100\% responden menyatakan BMT As Salam selalu datang terjadwal untuk melihat perkembangan usaha, sehingga mengetahui perkembangan usaha anggota, dan ramah dalam pelayanan konsultasi perkembangan usahatani. Akan tetapi, BMT As Salam kurang aktif dalam memberi masukan, arahan, maupun motivasi dalam menjalankan usahatani. Pihak BMT mengetahui perkembangan usaha responden dan memberi kepercayaan kepada responden karena responden memiliki jarak tempat tinggal yang terjangkau dari BMT, yaitu berkisar antara 0.3 sampai $3.5 \mathrm{~km}$, dan lahan tani yang digarap responden berdekatan dengan lahan tani yang digarap pihak BMT.

Total skor efektivitas pada tahap pengajuan pembiayaan sebesar 240, dengan persentase sebesar $88.9 \%$. Hal ini menunjukkan bahwa aspek pemanfaatan pembiayaan yang dilakukan oleh BMT As Salam sudah efektif.

\section{Analisis Efektivitas Penerapan Yarnen Tahap Pengembalian Pembiayaan}

Pada tahap pengembalian pembiayaan murabahah yarnen, BMT As Salam menetapkan margin berdasarkan pembiayaan yang diterima anggota. Semakin tinggi pembiayaan yang diterima anggota, maka semakin kecil margin yang dibebankan. Sebanyak 96.7\% responden menyatakan besar margin murabahah yang ditetapkan BMT As Salam 
tergolong ringan karena tidak memberatkan. Sebanyak 3.3\% responden menyatakan besar margin tergolong sedang karena masih terjangkau, walaupun terkadang telat membayar. Besar margin yang ditetapkan BMT As Salam pada responden berkisar antara 3.25\%-3.5\% tergantung pembiayaan yang diterima. Pilihan anggota untuk membayar margin setiap bulan maupun setelah panen tidak memengaruhi besarnya margin yang harus dibayar.

Jangka waktu pengembalian pokok pembiayaan murabahah yarnen adalah 6 bulan.Jangka waktu pengembalian disesuaikan dengan masa tanam hingga panen yang dibutuhkan petani padi.Sebanyak $93.3 \%$ responden menyatakan jangka waktu pengembalian tergolong sedang dan $6.7 \%$ menyatakan jangka waktunya cepat.Perbedaan persepsi ini tidak memengaruhi responden dalam mengembalikan pokok pembiayaan, karena responden mampu mengembalikan pokok pembiayaan tepat waktu.

Sebanyak $100 \%$ responden mengaku aktif mengantarkan sendiri margin maupun pengembalian pokok pembiayaan ke BMT As Salam. Berdasarkan hasil wawancara dengan pihak BMT, anggota memang diakui aktif mengantarkan sendiri margin maupun pengembalian pokok pembiayaan tersebut.

Total skor efektivitas pada tahap pengembalian pembiayaan sebesar 237, dengan persentase sebesar $87.8 \%$. Hal ini menunjukkan bahwa aspek pengembalian pembiayaan yang dilakukan oleh BMT As Salam sudah efektif.

\section{Analisis Efektivitas Penerapan Yarnen terhadap Aspek Ekonomi}

Aspek ekonomi responden setelah mendapat pembiayaan murabahah yarnen dari BMT As Salam ada yang tetap maupun mengalami peningkatan. Berdasarkan hasil wawancara, hal ini disebabkan beberapa faktor, antara lain keputusan anggota untuk menambah lahan atau tidak dan beragamnya pemanfaatan pendapatan usahatani. Skala usahatani yang diperhitungkan dalam aspek ekonomi ini adalah omzet usahatani sebelum dan setelah mendapat pembiayaan murabahah yarnen.

Sebanyak $66.2 \%$ responden menyatakan skala usahatani dan tingkat pendapatan usahatani meningkat dengan menambah lahan garap maupun membeli sarana produksi pertanian sendiri, setelah mendapat pembiayaan murabahah yarnen. Sebanyak 33.8\% menyatakan skala usahatani dan tingkat pendapatan usahatani tetap setelah mendapat pembiayaan murabahah yarnen. Hal ini disebabkan responden tidak menambah lahan garap.

Sebanyak $63.2 \%$ responden menyatakan aset yang dimiliki mengalami peningkatan.Aset tersebut meliputi kendaraan dan lahan pertanian.Sebanyak 36.8\% responden menyatakan aset yang dimiliki tetap. Responden memiliki beragam alasan, antara lain karena pendapatan digunakan untuk memperbaiki rumah maupun biaya pendidikan anak.

Karakteristik usahatani petani padi yang meliputi omzet usahatani, pendapatan usahatani, lama usahatani, dan luas lahan tani dapat memiliki hubungan satu sama lain. Hubungan lama usahatani dan luas lahan tani yang dimiliki maupun digarap petani padi dengan omzet usahani per musim (Tabel 7 dan Tabel 8). 
Tabel 7 Hubungan lama usahatani dan omzet usahatani per musim

\begin{tabular}{|c|c|c|c|c|c|c|}
\hline \multirow{2}{*}{$\begin{array}{l}\text { Lama } \\
\text { usahatani } \\
\text { (tahun) }\end{array}$} & \multicolumn{5}{|c|}{ Omzet usahatani per musim (orang) } & \multirow[t]{2}{*}{ Total } \\
\hline & $<\mathrm{Rp} 5 \mathrm{jt}$ & Rp 5-10jt & Rp 11-21jt & Rp 22-32jt & $>\mathrm{Rp} 32 \mathrm{jt}$ & \\
\hline$<10$ & - & 2 & 2 & 1 & - & 5 \\
\hline $10-20$ & 2 & 3 & 6 & - & - & 11 \\
\hline $21-31$ & - & 2 & 4 & 2 & - & 8 \\
\hline $32-42$ & - & 1 & 2 & 1 & - & 4 \\
\hline$>42$ & - & 1 & - & - & 1 & 2 \\
\hline Total & 2 & 9 & 14 & 4 & 1 & 30 \\
\hline
\end{tabular}

Lama usahatani petani padi tidak berhubungan dengan omzet usahatani. Hal ini dapat dilihat pada sebaran responden dengan lama usahatani kurang dari 10 tahun hingga lebih dari 42 tahun yang menyebar pada omzetsebesar Rp 5-10 juta, yaitu sebanyak 9 responden, dan pada omzet sebesar Rp 11-21 juta, yaitu sebanyak 14 responden. Sebaran tersebut menunjukkan semakin lama usahatani belum mampu signifikan meningkatkan omzet usahatani.

Tabel 8 Hubungan luas lahan tani dan omzet usahatani per musim

\begin{tabular}{|l|r|r|r|r|r|r|}
\hline \multirow{2}{*}{$\begin{array}{c}\text { Luas } \\
\text { laha } \\
\text { (ha) }\end{array}$} & \multicolumn{5}{|c|}{ Omzet usahatani per musim (orang) } & Total \\
\cline { 2 - 6 } & $<$ Rp 5 jt & Rp 5-10jt & Rp 11-21jt & Rp 22-32jt & $>$ Rp 32jt & \\
\hline 0.175 & 2 & - & - & - & - & 2 \\
\hline 0.35 & - & 5 & - & - & - & 5 \\
\hline 0.525 & - & 1 & - & - & - & 1 \\
\hline 0.7 & - & 3 & 12 & 4 & - & 19 \\
\hline$>0.7$ & - & - & 2 & - & 1 & 3 \\
\hline Total & 2 & 9 & 14 & 4 & 1 & 30 \\
\hline
\end{tabular}

Sebanyak 12 dari 30 responden memiliki maupun menggarap lahan tani seluas 0.7 ha dengan omzet berkisar Rp 11-21 juta.Jika dibandingkan dengan omzet usahatani yang didapat dari lahan tani seluas 0.525 ha, yaitu berkisar Rp 5-10 juta, dengan peningkatan luas lahan menjadi 0.7 ha, omzet dapat meningkat mencapai kisaran Rp 22-32 juta.Hal ini menunjukkan, semakin besar luas lahan yang digarap, omzet usahatani yang didapat semakin besar.

Tingkat pendapatan usahatani, seperti omzet usahatani, juga tidak memiliki hubungan dengan lama usahatani (Tabel 9). 
Tabel 9 Hubungan lama usahatani dan pendapatan usahatani per musim

\begin{tabular}{|l|r|r|r|r|r|}
\hline \multirow{2}{*}{$\begin{array}{c}\text { Lama } \\
\text { usahatani } \\
\text { (tahun) }\end{array}$} & \multicolumn{4}{|c|}{ Pendapatan usahatani per musim (orang) } & \multirow{2}{*}{ Total } \\
\cline { 2 - 5 } & $<$ Rp5jt & Rp 5-10jt & Rp 11-21jt & Rp 22-32jt & \\
\hline 10 & 1 & 1 & 3 & - & 5 \\
\hline $10-20$ & 3 & 6 & 2 & - & 11 \\
\hline $21-31$ & 1 & 3 & 4 & - & 8 \\
\hline $32-42$ & - & 2 & 1 & 2 & 5 \\
\hline$>42$ & - & 1 & - & - & 1 \\
\hline Total (orang) & 5 & 13 & 10 & 2 & 30 \\
\hline
\end{tabular}

Sebaran responden dengan lama usahatani kurang dari 10 tahun hingga lebih dari 42 tahun yang menyebar pada pendapatan sebesar Rp 5-10 juta, yaitu sebanyak 13 responden, dan pada omzet sebesar Rp 11-21 juta, yaitu sebanyak 10 responden. Sebaran tersebut menunjukkan semakin lama usahatani belum mampu signifikan meningkatkan pendapatan usahatani.

Tabel 10 Hubungan luas lahan tani dan pendapatan usahatani per musim

\begin{tabular}{|l|r|r|r|r|r|}
\hline \multirow{2}{*}{$\begin{array}{c}\text { Luas lahan } \\
\text { tani (ha) }\end{array}$} & \multicolumn{4}{|c|}{ Pendapatan usahatani per musim (orang) } & Total \\
\cline { 2 - 6 } & $<$ Rp5jt & Rp 5-10jt & Rp 11-21jt & Rp 22-32jt & \\
\hline 0.175 & 2 & - & - & - & 2 \\
\hline 0.35 & 3 & 2 & - & - & 5 \\
\hline 0.525 & - & 1 & - & - & 1 \\
\hline 0.7 & - & 10 & 5 & - & 15 \\
\hline$>0.7$ & - & - & 5 & 2 & 7 \\
\hline Total & 5 & 13 & 10 & 2 & 30 \\
\hline
\end{tabular}

Sebanyak 10 dari 30 responden memiliki maupun menggarap lahan tani seluas 0.7 ha dengan pendapatan berkisar Rp 5-10 juta. Jika dibandingkan dengan pendapatan usahatani yang didapat dari lahan tani seluas 0.525 ha, yaitu berkisar Rp 5-10 juta, dengan peningkatan luas lahan menjadi $0.7 \mathrm{ha}$, besar pendapatan yang diperoleh relatif sama, yaitu Rp 5-10 juta. Hal ini dapat disebabkan adanya peningkatan luas lahan tani juga menimbulkan peningkatan pada biaya produksi pertanian, sehingga pendapatan usahataninya tidak berbeda.

Total skor efektivitas pada tahap pengajuan pembiayaan sebesar 230, dengan persentase sebesar $85.2 \%$. Hal ini menunjukkan bahwa pembiayaan murabahah yarnen diBMT As Salam memberi dampak positif bagi anggota dan sudah efektif. 
SIMPULAN DAN SARAN

\section{Simpulan}

Berdasarkan hasil penelitian, maka diperoleh kesimpulan sebagai berikut:

1. Variabel yang signifikan memengaruhi petani padi dalam memilih sistem pembayaran margin pada pembiayaan akad murabahah pertanian padi di BMT AsSalam pada taraf nyata 5\% adalah dummy alasan pemilihan kedua, yaitu alasan memilih sistem pembayaran karena lebih ringan, dengan nilai odds ratio sebesar 0.026. Alasan lebih ringan untuk memilih pembayaran margin yarnen memiliki peluang lebih kecil dibandingkan alasan sesuai kemampuan. Hal ini menunjukkan responden memiliki peluang lebih besar memilih yarnen karena sesuai kemampuan pembayaran.

2. Penerapan yarnen pada pengembalian pembiayaan akad murabahah pertanian padi di BMT As-Salam sudah efektif di seluruh tahapan pembiayaan dan memberi dampak positif pada usahatani anggota. Hal ini menunjukkan penerapan yarnen telah mencapai tujuannya, yaitu menerapkan sistem yang sesuai dengan kondisi petani. Akan tetapi, ada syarat dan rukun akad, serta prinsip keadilan ekonomi yang belum terpenuhi.

\section{Saran}

Hasil penelitian menunjukkan bahwa sistem pengembalian murabahah yarnen yang diterapkan BMT As Salam mampu memberi dampak positif bagi anggota. Saran yang diberikan berdasarkan penelitian ini adalah:

1. Penerapan akad murabahah belum sesuai dengan prinsip syariah karena BMT tidak langsung menyediakan barang yang dibutuhkan oleh anggota yang mengajukan pembiayaan, melainkan dalam bentuk uang tunai. BMT dapat menyesuaikan penerapan murabahah yang sesuai prinsip syariah dan memenuhi syarat dan rukun akad murabahah.

2. Biaya administrasi yang dibebankan oleh BMT kepada anggota yang menerima pembiayaan tidak sesuai dengan perintah berlaku adil dalam transaksi ekonomi karena penentuannya berdasarkan persentase pembiayaan yang diterima. BMT dapat menetapkan standar biaya administrasi untuk pembiayaan sesuai dengan keperluan administrasi pembiayaan, bukan dengan persentase.

3. Penyewaan lahan pertanian dilarang dalam Islam, sehingga pengelolaan lahan pertanian dapat dilakukan dengan akad kerjasama, bukan sewa-menyewa.

4. BMT As Salam terus berusaha menyesuaikan sistem pembiayaan pertanian dengan kondisi petani sebagai anggota dan mempertahankan efektivitas penerapan sistem tersebut

5. BMT lain dapat menerapkan sistem pembiayaan murabahah yarnen dengan penyesuaian kondisi petani di lokasi sasaran BMT 
6. Pengembalian petani padi di BMT As Salam, yang tergolong lancar, dapat diteliti lebih lanjut untuk mengetahui faktor apa yang memengaruhinya, sehingga BMT dapat mengetahui apakah petani padi yang menerima pembiayaan memiliki potensi pengembalian lancar.

\section{DAFTAR PUSTAKA}

Akdon, R. 2009. Rumus dan Data dalam Analisis Statistika. Bandung (ID): Alfabeta.

Aminullah M. 2014. Pola Pemberdayaan Petani Peserta Program GP3K (Gerakan Peningkatan Produktivitas Pangan Berbasis Korporasi) Binaan PT. Pusri Palembang. Jurnal Ilmiah AgrIBA. [internet]. [diunduh 2014 Jun 4 ]. No. 2 Edisi Maret 2014. Tersedia pada: http://jurnal-agriba.info/wpcontent/uploads/2014/04/1-Aminullah.pdf

Anjani SS. 2013. Analisis Efektivitas Pembiayaan Syariah bagi Sektor Pertanian pada KBMT Ibaadurrahman, Ciawi, Bogor. [skripsi]. Bogor (ID): Institut Pertanian Bogor.

Ashari, S. 2005. Prospek Pembiayaan Syariah untuk Sektor Pertanian.Forum Penelitian Agro Ekonomi[internet]. [diunduh 2014 Jan 20]. Volume 23(2): 132-147

[BPS] Badan Pusat Statistik. 2010. Jumlah Penduduk Indonesia menurut Provinsi. [internet]. [diunduh 2014 Jun 24]. Tersedia pada: http://bps.go.id

[DSN-MUI] Dewan Syariah Nasional-Majelis Ulama Indonesia. 2000. Fatwa DSN MUI No. 04/DSN-MUI/IV/2000 Tentang Murabahah.

[Kementan RI] Kementerian Pertanian RI. 2013. Konsumsi Rata-rata per Kapita Setahun Beberapa Bahan Makanan di Indonesia.[internet]. [diunduh 2014 Mei 20]. Tersedia pada: http://www.pertanian.go.id/Indikator/tabe15b-konsumsi-rata.pdf

Kusmiyati ANS. 2007. Risiko Akad dalam Pembiayaan Murabahah pada BMT di Yogyakarta (dari Teori ke Terapan).Jurnal La Riba.[internet]. [diunduh 2014 Feb 5]. Tersedia pada:http://journal.uii.ac.id/index.php/ JEI/article/viewFile/1045/970.

Ma'turidi DH, Syukur M. 2008. Pembiayaan Syariah dalam Pembangunan Pertanian.Jakarta: Pusat Pembiayaan Pertanian, Sekretariat Jenderal Departemen Pertanian.

Mosher AT. 1987. Menggerakkan dan Membangun Pertanian. Krisnandhi S, Samad B, penyadur. Jakarta (ID): Yasaguna. Terjemahan dari: Getting Agriculture Moving.

Nawai N, Shariff MNM. 2012. Factor Affecting Repayment Performance in Microfinance Programs in Malaysia. Procedia - Social and Behavioral Sciences. [internet]. [diunduh 2014 Mar 11].62 (2012): 806-811. Tersedia pada:http://www.sciencedirect.com/science/article/pii/ S187704281203577X

Nawawi I. 2012. Fikih Muamalah : Klasik dan Kontemporer. Bogor (ID) : Ghalia Indonesia. 
Riduwan, S. 2011. Pengantar Statistika untuk Penelitian Pendidikan, Sosial, Komunikasi, Ekonomi, dan Bisnis.Bandung (ID): Alfabeta.

Saptia Y. 2009. Efektivitas Model Pembiayaan Syariah dalam Mengembangkan Sektor Pertanian.[internet]. [diunduh 2014 Jan 28]. Tersedia pada: http://perpustakaan.ekonomi.lipi.go.id.

Soekartawi. 2002. Prinsip Dasar Ekonomi Pertanian: Teori dan Aplikasi. Jakarta (ID): PT. Raja Grafindo Persada.

Soemitra A. 2009. Bank dan Lembaga Keuangan Syariah.Jakarta (ID): Prenada Kencana.

Tampubolon SMH. 2002. Suara dari Bogor: Sistem dan Usaha Agribisnis Kacamata Sang Pemikir. Bogor (ID): Pusat Studi Pembangunan IPB \& USESE Foundation. 